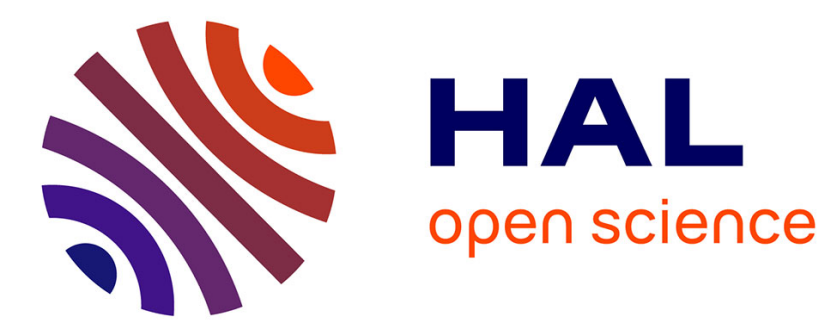

\title{
Sustainable Agriculture Reviews
}

Eric Lichtfouse

\section{To cite this version:}

Eric Lichtfouse. Sustainable Agriculture Reviews. Springer Science, 12, 372 p., 2013, Sustainable Agriculture Reviews, 978-94-007-5960-2 978-94-007-5961-9 (eBook). 10.1007/978-94-007-5961-9 . hal02809474

\section{HAL Id: hal-02809474 \\ https://hal.inrae.fr/hal-02809474}

Submitted on 6 Jun 2020

HAL is a multi-disciplinary open access archive for the deposit and dissemination of scientific research documents, whether they are published or not. The documents may come from teaching and research institutions in France or abroad, or from public or private research centers.
L'archive ouverte pluridisciplinaire HAL, est destinée au dépôt et à la diffusion de documents scientifiques de niveau recherche, publiés ou non, émanant des établissements d'enseignement et de recherche français ou étrangers, des laboratoires publics ou privés. 


\title{
Sustainable Agriculture Reviews
}

\author{
Volume 12
}

\section{Series Editor}

Eric Lichtfouse

For further volumes:

http://www.springer.com/series/8380 
Sustainable Agriculture

Sustainable Agriculture, Volume 2

Organic Farming, Pest Control and Remediation of Soil Pollutants

Climate Change, Intercropping, Pest Control and Beneficial Microorganisms

Sociology, Organic Farming, Climate Change and Soil Science

Genetic Engineering, Biofertilisation, Soil Quality and Organic farming

Biodiversity, Biofuels, Agroforestry and Conservation Agriculture

Alternative Systems, Biotechnology, Drought Stress and Ecological Fertilisation

Genetics, Biofuels and Local Farming Systems

Agroecology and Strategies for Climate Change

Organic Fertilisation, Soil Quality and Human Health

Environmental Chemistry. Green Chemistry and Pollutants in Ecosystems

Farming for Food and Water Security

Environmental Chemistry for a Sustainable World

Volume 1. Nanotechnology and Health Risk

Environmental Chemistry for a Sustainable World

Volume 2. Remediation of Air and Water Pollution

Rédiger pour être publié ! Conseils pratiques pour les scientifiques

\section{Call for review articles}

Authors wishing to publish a review article in Sustainable Agriculture Reviews or Environmental Chemistry for a Sustainable World should contact the Editor.

E-mail: Eric.Lichtfouse@dijon.inra.fr

* Eric Lichtfouse is Chief Editor and founder of impact-factor journals and book series. He is giving conferences, lectures and workshops on scientific writing and communication in Europe and the USA. He has founded publication assistance services to help authors, institutes and universities. For further information see LinkedIn, ResearchID and Google Scholar Citations. 
Eric Lichtfouse

Editor

\section{Sustainable Agriculture Reviews}

包 Springer 


\author{
Editor \\ Eric Lichtfouse \\ INRA-CMSE-PME, UMR1347 \\ Agroécologie \\ 17, rue Sully, 21000 Dijon \\ France
}

ISSN 2210-4410

ISSN 2210-4429 (electronic)

ISBN 978-94-007-5960-2

ISBN 978-94-007-5961-9 (eBook)

DOI 10.1007/978-94-007-5961-9

Springer Dordrecht Heidelberg New York London

Library of Congress Control Number: 2013932220

(C) Springer Science+Business Media Dordrecht 2013

This work is subject to copyright. All rights are reserved by the Publisher, whether the whole or part of the material is concerned, specifically the rights of translation, reprinting, reuse of illustrations, recitation, broadcasting, reproduction on microfilms or in any other physical way, and transmission or information storage and retrieval, electronic adaptation, computer software, or by similar or dissimilar methodology now known or hereafter developed. Exempted from this legal reservation are brief excerpts in connection with reviews or scholarly analysis or material supplied specifically for the purpose of being entered and executed on a computer system, for exclusive use by the purchaser of the work. Duplication of this publication or parts thereof is permitted only under the provisions of the Copyright Law of the Publisher's location, in its current version, and permission for use must always be obtained from Springer. Permissions for use may be obtained through RightsLink at the Copyright Clearance Center. Violations are liable to prosecution under the respective Copyright Law.

The use of general descriptive names, registered names, trademarks, service marks, etc. in this publication does not imply, even in the absence of a specific statement, that such names are exempt from the relevant protective laws and regulations and therefore free for general use.

While the advice and information in this book are believed to be true and accurate at the date of publication, neither the authors nor the editors nor the publisher can accept any legal responsibility for any errors or omissions that may be made. The publisher makes no warranty, express or implied, with respect to the material contained herein.

Printed on acid-free paper

Springer is part of Springer Science+Business Media (www.springer.com) 


\section{Contents}

Surprising Facts About Soils, Students and Teachers!

A Survey of Educational Research and Resources

Douglas Hayhoe

Sustainable Agriculture and Climate Changes in Egypt.

Hassan R. El-Ramady, Samia M. El-Marsafawy, and Lowell N. Lewis

Adapting Maize Crop to Diverse Agro-Ecosystems.

Ioannis S. Tokatlidis

Intercropping

Ehsan Neamatollahi, Mohammad Reza Jahansuz, Dariush Mazaheri, and Mohammad Bannayan

\section{Enhancing Fertilizer Efficiency in High Input}

Cropping Systems in Florida

Johannes M.S. Scholberg, Lincoln Zotarelli, Michael D. Dukes,

Monica Ozores-Hampton, Guodong Liu, and Pablo Tittonell

Soil Organic Matter Dynamics and Structure

Nikolaos P. Nikolaidis and G. Bidoglio

Plant and Animal Breeding as Starting Points

for Sustainable Agriculture

Gerhard Flachowsky, Ulrich Meyer, and Manfred Gruen

Medicinal Plant Active Compounds Produced

by UV-B Exposure.

Rima Kumari and Majeti Narasimha Vara Prasad 
Assessing the Environmental Benefits of Compost

Use-on-Land through an LCA Perspective.

Julia Martínez-Blanco, Cristina Lazcano, Alessio Boldrin,

Pere Muñoz, Joan Rieradevall, Jacob Møller, Assumpció Antón, and Thomas H. Christensen

Biocontrol of Plant Pathogens Using Plant

Growth Promoting Bacteria.

Pratibha Prashar, Neera Kapoor, and Sarita Sachdeva

Index 